\title{
Sex Ratio, Gonad Maturity and Size-Structure of Pagelus bellotti in Sierra Leone
}

\author{
${ }^{* 1}$ MANSARAY, A; ${ }^{2}$ KONOYIMA, KJ

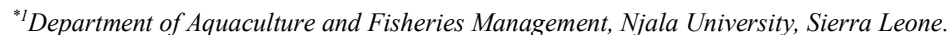 \\ ${ }^{2}$ Institute of Marine Biology and Oceanography, University of Sierra Leone, Sierra Leone. \\ *Corresponding Author Email: amidu.mansaray@njala.edu.sl; Other Author Email: komba.konoyima@usl.edu.sl
}

\begin{abstract}
A total of 135 specimens of Pagellus bellotti were randomly collected from artisanal boats in August 2018. Study of sex ratio, gonad maturity and size-structure of Pagellus bellottii is meagre in Sierra Leone, and forms the basis of the present study. The study will contribute to current knowledge and promote rational exploitation of the stock. Length and weight were measured using a fish measuring board $(\mathrm{cm})$ and digital weight scale $(\mathrm{g})$ respectively. Sex and gonad maturity were macroscopically assessed. Results showed dominant males $(71.9 \%)$ and significant difference observed (1:2.6) and expected (1:1) female: male sex ratios $(\mathrm{p}<0.05)$. Only $11.9 \%$ and $11.1 \%$ of male and female gonads transcended to the developed stage (Stage IV). The length-frequency distribution for combined sex was unimodal (modal class, $17 \mathrm{~cm}-20.9 \mathrm{~cm})$. Mean length and weight respectively were, $19.04 \pm 0.32 \mathrm{~cm}$ and $98.85 \pm 5.08 \mathrm{~g}$ for males and $17.43 \pm 0.54 \mathrm{~cm}$ and $78.61 \pm 6.32 \mathrm{~g}$ for females. Growth exponent (b) for male, female and combined sex was $2.809,2.928$ and 2.850 respectively and the correlation coefficient for all sex categories showed $(r>0.9)$. Indexes of condition were greater than $1.0(\mathrm{~K}>1)$ for all sex categories. Results portrayed a heterogeneous gender population of Pagelus bellottii and vast similarity in reproductive strategies by both sexes. The fish comprised of one size group and males may be growing larger than the females. Growth pattern was near-isometric for females and negative allometric for the males, and both sexes were in better condition $(\mathrm{K}>1.0)$. An annual study could provide further insight.
\end{abstract}

\section{DOI: $\underline{\text { https://dx.doi.org/10.4314/jasem.v24i12.22 }}$}

Copyright: Copyright (C) 2020 Mansaray and Konoyima. This is an open access article distributed under the Creative Commons Attribution License (CCL), which permits unrestricted use, distribution, and reproduction in any medium, provided the original work is properly cited.

Dates: Received: 01 October 2020; Revised: 20 November 2020; Accepted: 16 December 2020

Keywords: Allometric growth, cohort, condition factor, gonad maturity, isometric growth.

Fish is an economically viable natural capital (Famoofo and Abdul, 2017) that contains essential body building nutrients (Beveridge et al., 2013), and much preferred to any other type of meat (Konoyima, 2020). Besides, fish contributes to about $80 \%$ of the Sierra Leonean protein diets (Neiland et al., 2016) and GDP of $12 \%$ (Konoyima et al., 2020). Pagellus bellottii (Steindachner, 1882) is commonly known as the red Pandora, a demersal fish species of the Sparidae family that inhabit hard or sandy bottoms in coastal marine waters at depths between $10 \mathrm{~m}$ and $50 \mathrm{~m}$ but could move up to $250 \mathrm{~m}$ depth (Kouame et al., 2018). The red Pandora is known to occur in the Gulf of Guinea (Fischer et al., 1987) with wide distribution in the Eastern Atlantic (Bauchot and Hureau, 1986). Moreover, Pagellus bellotti is one of the most economically important and diverse marine teleost of the West African Coast (Kouame et al., 2018), and a critically important component of the multi-species coastal demersal fisheries in the Eastern Central Atlantic (Russell and Carpenter, 2014). Biological studies are known to provide unwavering and vital information for fisheries resources management (Ahmed et al., 2011). Length-frequency data are useful indices of cohorts of stocks (Cunha et al., 2007) while length-weight relationship inform of growth pattern and for estimating average weight of a given length group of fish species (Pauly, 1993; Amponsah et al., 2017). The condition factor (K) and gonadal development of a fish provide insights on the environmental suitability and spawning cycle (Adebiyi, 2013a; 2013b; Amponsah et al., 2017; Konoyima et al., 2020). Growth pattern of a fish is said to be allometric when the growth exponent, $\mathrm{b}<3$ or $\mathrm{b}$ $>3$, and isometric when, $b=3$ (Pauly, 1984; Froese, 2006). Sex ratio provide information about the proportion of male and female, indicative of the reproductive potentials and predictability of stock size of fish population (Vicentini and Araujo, 2003). Study of sex ratio, gonad maturity and size-structure of Pagellus bellottii is meagre in Sierra Leone, and forms the basis of the present study. The study will contribute to current knowledge and promote rational exploitation of the stock of P. bellottii.

\section{MATERIALS AND METHODS}

Study Area: Sierra Leone is a small country covering an area of approximately $72,000 \mathrm{~km}^{2}$ lying between latitudes $7^{\circ}$ and $10^{\prime} \mathrm{N}$ and longitudes $10^{\circ} 14^{\prime} \mathrm{W}$ and situated on the Atlantic coast of West Africa, with a 
coastline of about $560 \mathrm{~km}$ long, 200 nautical miles territorial sea limit and 5 to 6 nautical miles inshore exclusion zone (IEZ) (Neiland et al., 2016). The Continental Shelf area is about $30,000 \mathrm{~km}^{2}$ and an Exclusive Economic Zone of about 155,700 km² (Sheriff et al., 2009).

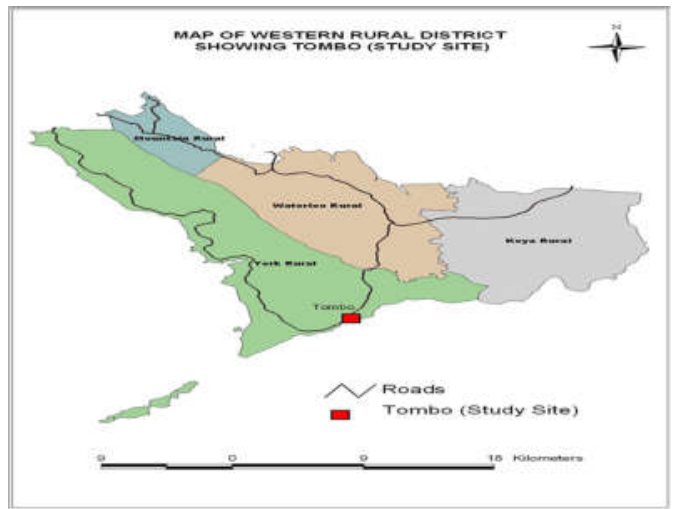

Fig. 1: Sampling location

The climate is mainly tropical with two distinct seasons: the dry season that lasts from NovemberApril and the monsoonal rainy season which lasts from May-October (Coutin and Payne, 1988). Fish specimens were collected from artisanal fishing boats at Tombo Fish Landing Site in Yawri Bay, Western
Area Rural District, Sierra Leone located at $08^{\circ} 12.837^{\prime}$ $\mathrm{N}$ and $013^{\circ} 05.657^{\prime} \mathrm{W}$. Figure 1 shows the location of the landing site.

Sampling Design and Data Collection: A total of 135 fish specimens of Pagellus bellottii were collected at random in August, 2018 from artisanal fishers who used various fishing gears such as gill nets, long-lines and seine nets. The randomized sampling technique ensured unbiased samples. The collected specimens were preserved in ice-boxes and transported to the laboratory of the department of Aquaculture and Fisheries, Njala University, for further analysis.

Identification and Measurements: Specimens of Pagellus bellotii were clearly distinguished from other sparids using the FAO Fish Identification Guide (FAO, 1999; 2010) using its peculiar features such as: number of rays and spines, mouth pattern, type of tail, position of the lateral line etc. Length and weight measurements were completed using a one-meter fish measuring board (nearest $1 \mathrm{~cm}$ ) and digital electronic weight scale to the nearest $0.01 \mathrm{~g}$ (ADAMACBPlus600H). Fish specimens were dissected and sexes identified based on gonad differences while determination of gonad maturity stages was by visual examination of the gonads using maturity keys by Fontana (1969) as given in Table 1.

\begin{tabular}{|c|c|c|}
\hline Stages & Testes (male) & Ovary (female) \\
\hline Stage I (Immature) & $\begin{array}{l}\text { Testis thin, slender, translucent and pale } \\
\text { in colour }\end{array}$ & Ovary very small, thin, thread like and pale \\
\hline $\begin{array}{l}\text { Stage II (Early- } \\
\text { maturing ) }\end{array}$ & $\begin{array}{l}\text { Testis gets enlarged, flat, and cream-white } \\
\text { in colour. }\end{array}$ & Ovary becomes slightly larger and translucent. \\
\hline Stage III (Developing) & $\begin{array}{l}\text { Testis much enlarged and heavier, light } \\
\text { pinkish and looks more vascular. }\end{array}$ & $\begin{array}{l}\text { Ovary large, opaque and light yellow in colour, blood vessels } \\
\text { become visible on the surface }\end{array}$ \\
\hline $\begin{array}{l}\text { Stage } \\
\text { (Developed/Pre } \\
\text { spawning ) }\end{array}$ & $\begin{array}{l}\text { Testis overly much enlarged and turns } \\
\text { milky white. White milt release with a } \\
\text { slight pressure. }\end{array}$ & $\begin{array}{l}\text { Ovary overly much enlarged occupying almost the entire body } \\
\text { cavity, yellowish in colour and eggs were clearly visible. }\end{array}$ \\
\hline Stage V (Spawning) & $\begin{array}{l}\text { Testis became flabby, thin and dull white } \\
\text { in colour. }\end{array}$ & $\begin{array}{l}\text { Ovary walls become thin almost transparent. Ripe eggs are visible } \\
\text { through the ovarian wall and some ripe eggs have begun to extract } \\
\text { through the oviduct. }\end{array}$ \\
\hline Stage VI (Spent) & $\begin{array}{l}\text { Testis became flaccid empty with } \\
\text { evidence of blooding. }\end{array}$ & $\begin{array}{l}\text { Ovary flaccid, sac like and reduced in volume. Ovary contains } \\
\text { ripe un-spawned and darkened eggs, numerous small ova. }\end{array}$ \\
\hline
\end{tabular}

Data analysis: The data obtained were used to compute

Percentage Sex Ratio: The percent sex ratio was computed as follows

$$
\text { Sex Ratio }=n F / n M * 100
$$

Where $\mathrm{n}=$ number, $\mathrm{F}=$ female and $\mathrm{M}=$ male).

Length-Weight Relationships (LWR):
The total length and body weight of fish were used for the Length-Weight Relationships. The Length-Weight relationships were represented by the least square regression equation as follows:

$$
\mathrm{W}=a L^{b} \ldots \ldots(2)(\text { Le Cren, 1951; Pauly, 1983) }
$$

This was log transformed to have the logistic lengthweight relationship as:

$$
\log W=\mathrm{a}+\operatorname{blog} L \text { (Pauly, 1984). }
$$


$\mathrm{W}=$ Body weight of fish ( $\mathrm{g}) ; \mathrm{L}=$ Total length of fish $(\mathrm{cm}), \mathrm{a}=$ intercept, and $\mathrm{b}=$ Growth exponent/Slope.

Condition factor (K): The Fulton's Condition Factor (K) was calculated for all sex categories of the fish using the relation:

$$
K=100 * W / L^{3}
$$

Where: $\mathrm{K}=$ Condition Factor; $\mathrm{W}=$ the weight of the fish in gram $(\mathrm{g}) ; \mathrm{L}=$ the total length of the fish $(\mathrm{cm})$

Statistical analysis: Microsoft (MS) Excel (ver., 2016) data analysis package for PCs was used to compute the student's $t$-distribution test of significance, descriptive statistics and length-frequency distributions. Correlation coefficient ( $r$ ) was estimated by:

$$
r=S Q R T\left(R^{2}\right)
$$

Where $\mathrm{R}^{2}=$ Coefficient of determination obtained from the length-weight relationships (Konoyima 2020; Konoyima et al., 2020). Similarly, deviation between sex ratios was calculated using the Chi-Square test statistic (at 5\% significance). Moreover, the growth exponent (b) was checked for a significant deviation from the isometric value $(b=3.0)$ using the Student's ttest (at $\alpha=0.05$ ) using the formula and link:

$\mathrm{t}_{\mathrm{s}}=((b-3)) / S b$.

Where, $\mathrm{t}_{\mathrm{s}}=$ Student's t-test, $\mathrm{b}=$ slope/growth exponent and $\mathrm{S}_{\mathrm{b}}=$ standard error of the slope (Ogunola et al., 2018).

\section{RESULTS AND DISCUSSION}

Sex Ratio: Of the 135 recorded specimens, 97 were males $(71.9 \%)$ and 38 females $(28.1 \%)$, giving a female: male sex ratio of $1: 2.6$. The difference between observed (1:2.6) and expected (1:1) sex ratios was significant $\left(X^{2}{ }_{0.05}=10.08 ; p\right.$-value $=0.003 ; \alpha=5 \%$; df.1).

Stages of Gonad Maturity: Male specimens of $P$. bellottii had large number of gonads $(29.6 \%)$ in the developing stage (Stage 3) while $11 \%$ of both sexes had gonads in the pre-spawning stages (Figure 2).

\section{Size-Structure}

Length-Frequency Distribution: The length-frequency distribution curve (Figure 3) of Pagelus bellotti is symmetric and unimodal (modal class size, $17 \mathrm{~cm}-$ $20.9 \mathrm{~cm})$.

Length-Weight Relationship: Total length for combined sexes ranged from $9 \mathrm{~cm}$ to $28.5 \mathrm{~cm}$, mean
$18.59 \pm 0.28 \mathrm{~cm}$ while total weight ranged from $11 \mathrm{~g}$ to $371 \mathrm{~g}$ with a mean of $93.15 \pm 4.12 \mathrm{~g}$. Besides, total length and weight of female specimens respectively ranged from $9 \mathrm{~cm}-24 \mathrm{~cm}$ (mean, $17.43 \pm 0.54 \mathrm{~cm}$ ) and $11 \mathrm{~g}-167 \mathrm{~g}$ (mean, 78.61 $\pm 6.32 \mathrm{~g}$ ), while the males had lengths ranging from $11.5 \mathrm{~cm}-28.50 \mathrm{~cm}$ (mean, $19.04 \pm 0.32 \mathrm{~cm}$ ) and weights, 22g-371g (mean, 98.85 $\pm 5.08 \mathrm{~g}$ ). The regression parameters (coefficient of determination, $\mathrm{R}^{2}$; correlation coefficient, $\mathrm{r}$; intercept, $\mathrm{a}$; and growth exponent, $\mathrm{b}$ are given in Table 2 .

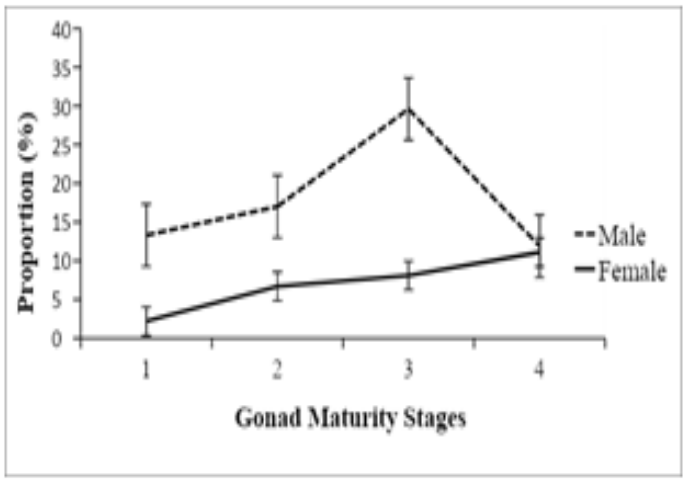

Fig. 2: Stages of Gonad maturity of Pagelus bellottii

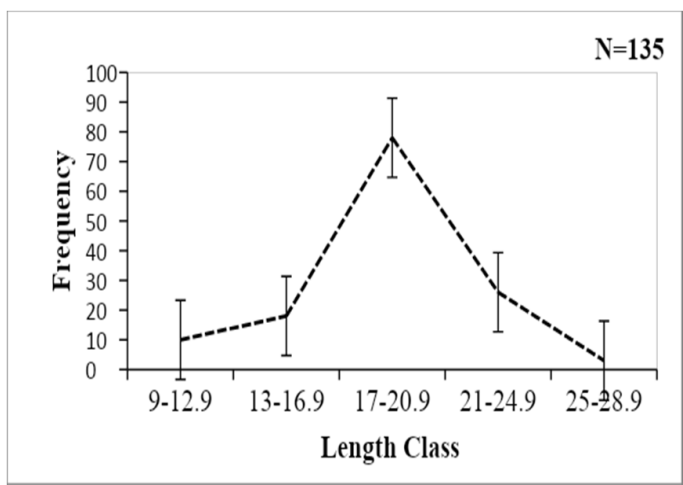

Fig 3: Length-frequency distribution of Pagelus bellotti

\begin{tabular}{llllll}
\multicolumn{6}{l}{ Table 2: Regression parameters of Pagellus bellottii } \\
\hline Sex & $\mathrm{n}$ & $\mathrm{R}^{2}$ & $\mathrm{r}$ & $\mathrm{a}$ & $\mathrm{b}$ \\
\hline Male & 97 & 0.88 & 0.94 & -1.63 & 2.81 \\
Female & 38 & 0.98 & 0.99 & -1.78 & 2.93 \\
Combined & 135 & 0.92 & 0.96 & -1.69 & 2.85 \\
\hline
\end{tabular}

The least squares regression and logistic length-weight relationships for male, female and combined sex are given in Figures 4 (a-f).

Condition Factor: The result for the condition factor for Pagellus bellotti showed the range of 1.00-3.53 with a mean of $1.35 \pm 0.30$ for males. Female values ranged from 1.12-1.65 with a mean of $1.35 \pm 0.13$, while $\mathrm{K}$-values for combined sexes ranged between 1.00 and 3.54 and mean of $1.35 \pm 0.27$. 
Sex and Gonad Maturity: The sex ratio of Pagellus bellotti significantly deviated from the expected ratio of $1: 1$, suggesting heterogeneity in gender populations of the fish, and the skewed population to the males portrayed vast vulnerability of males to capture. It could also be that mortality rates was high for the males compared with females.

Sylla et al. (2016) concur that sex ratio in fish populations is governed by a number of factors such as differences in mortality or longevity. Several authors have observed dissimilarity in gender populations for other Sparidae species of the genus, Pagellus (Bensahla, 2014; Benina 2015; Dobroslavić et al. 2017; Mahdi et al., 2017). Notwithstanding, Kouame et al. (2018) have noted unbiased sex ratios for $P$. bellottii while Dia et al. (2009) have noted similar gender population for Diplodus sargus cadenati of the Sparidae family.

Moreover, the uniformity in records of underdeveloped and pre-spawning gonads by both sexes of the study species suggested vast similarity in their reproductive strategies. Súarez et al. (2017) had earlier on shown the stages of gonadal development to be indicative of the reproductive potentials of a fish species.

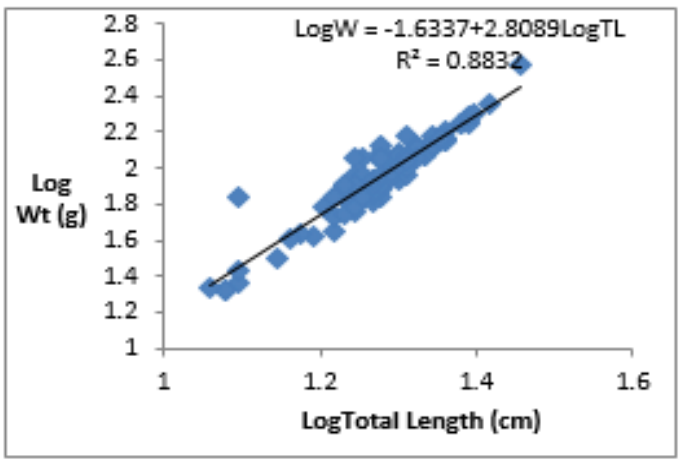

Fig 4a: Male logistic length-weight

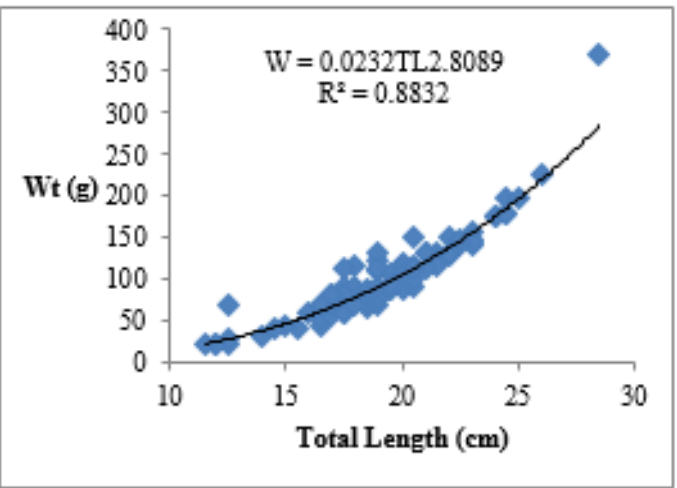

Fig 4b: Male least squares length weight

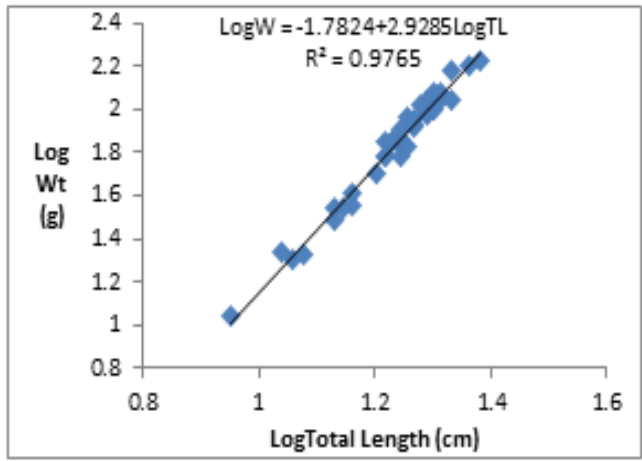

Fig 4c: Female logistic length-weight

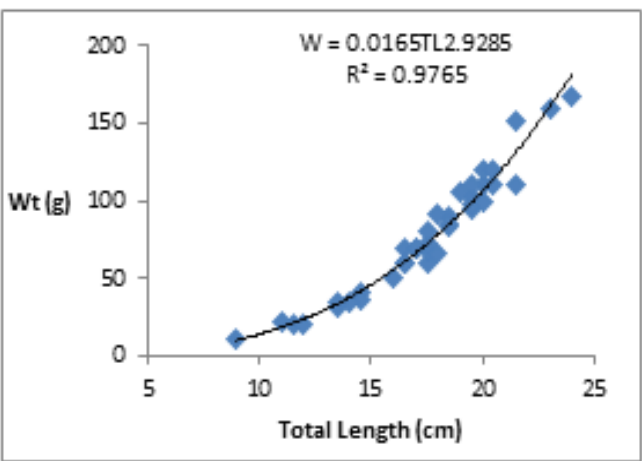

Fig 4d: Female least squares length-weight

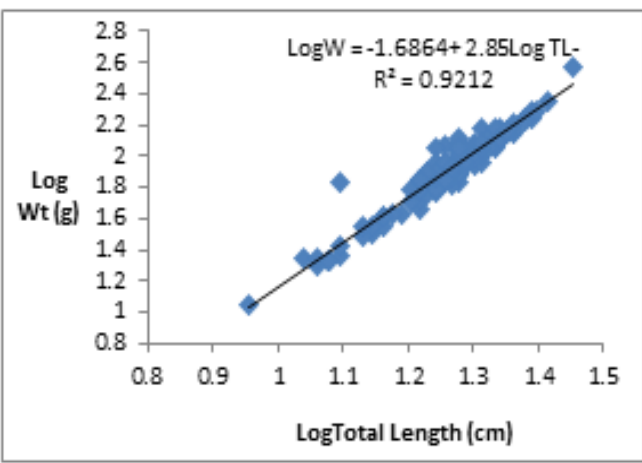

Fig 4e: Combined sex least squares length-weight

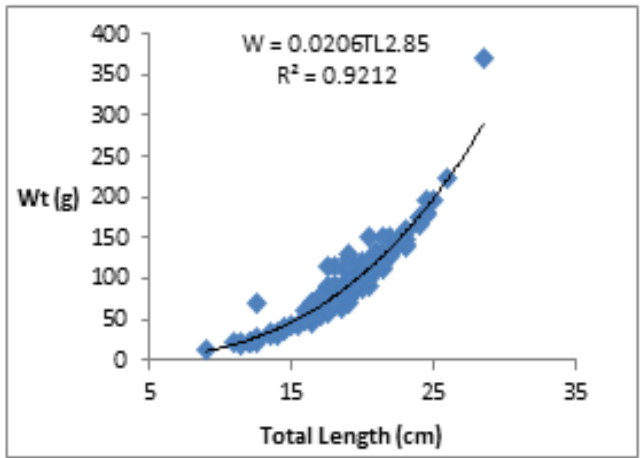

Fig 4f: Combined sex logistic Length-weight 
Size-Structure: The symmetric and unimodal lengthfrequency distribution suggested that the most commonly attainable length of pagellus bellottii ranged from $17 \mathrm{~cm}-21 \mathrm{~cm}$, characteristic of a single cohort species. Moreover, the variance in total lengths and body weights indicated that males plausibly grew larger than the females, while the estimated correlation coefficient $(r>0.9)$ was suggestive of vast correlation between length and weights of all sex categories. Besides, growth exponent (b) was indicative of negative allometric growth in the males $(\mathrm{b}<3.0)$ and isometric growth in the females $(b \approx 3.0$, at $p>0.05)$. This further suggested that the females maintained their shape as they grew in size while length and weight of the males did not grow at the same rate. These assertions are coherent with that of other scholars (Pauly, 1984; Froese, 2006; Amponsah et al., 2017; Konoyima, 2020; Konoyima et al., 2020). Moreover, the estimated ' $b$ ' value of both sexes from this study was in agreement with records by other authors whereby Showers (1993) obtained b value of 2.823 for P. bellottii in the Gulf of Guinea; Torres and Sobrino (2012) obtained b value of 2.990 in the Gulf of Cadiz in Spain and Druzhini (1976) recorded b value of 2.991 in North-West Africa. Also, the recorded " $b$ " value for both sexes was within the suggested range of 2.8-2.9 (Carlender, 1969; Tesch, 1971; Gayanilo and Pauly, 1997) and 2.5 and 3.5 (Thomas et al., 2003) for most tropical fish species.

Further, values of the condition factor $(\mathrm{K})$ were indicative of fat and healthy individuals of both sexes of Pagellus bellottii $(\mathrm{K}>1.0)$, which further suggested that environmental conditions were much favourable by the fish prior to sampling. Moreover, K-values of the males were, for the most part, higher than the females and were seemingly pursuant to earlier assertion that heavier fish of given length are in better health conditions than those of lesser weight (Le Cren, 1951; Agbugui, 2013). Other authors have inferred that $\mathrm{K}>1.0$ informs of better physiological state of fish from nutritional and reproductive outlook and reflects the degree of nourishment (Ayode, 2011; Adebiyi, 2013b).

Conclusion: Gender population of Pagellus bellottii was heterogeneous, and there may be vast similarity in the reproductive strategies between male and female specimens. The fish belonged to one-sized group mostly in the size range of $17 \mathrm{~cm}-21 \mathrm{~cm}$, and the males may be growing larger than the females. Males had positive allomertic growth pattern while the females showed isometric growth and all specimens were fat and healthy $(K>1.0)$. An annual study could provide further insight.
Acknowledgements: The authors extend gratitude to the Harbour Master and artisanal fishers at Tombo fish landing site for their show of support for the study.

\section{REFERENCES}

Adebiyi, FA (2013a). Growth pattern of the big eye grunt Brachydeuterus auritus (Valenciennes, 1832) off Lagos, Nigeria. IJF; 60 (3): 9-12.

Adebiyi, FA (2013b). Length frequency distribution, Length - weight relationship and condition factor of sompat grunt Pomadasys jubelini (Cuvier, 1830) off Lagos coast, Nigeria. Pertanika JTAS; 36 (4): 337-344.

Agbugui, MO (2013). Length-Weight relationship and condition factor of Pomadasys Jubeliniin the New Calabar-Bonny River, Nigeria. World Rural Observations; 5(4): 50-53

Agbugui, MO (2016). Aspects of the reproductive biology of the grunt, Pomadasys jubelini (Cuvier, 1830 ) in the New Calabar-Bonny River, Rivers State, Nigeria. IJSER; 7(10):1666- 1680.

Ahmed, EO; Ali, ME; Aziz, AA (2011).Length-weight relationships and condition factors of six fish species in Atbara River and Khashm el-girba Reservoir, Sudan. IJAS; 3 (1): 65-70.

Amponsah, SKK; Abdulhakim, A; Ofori-Danson, PK; Anyan, KF (2017). Population dynamics of bigeye grunt, Brachydeuterus auritus (Valenciennes, 1831) in Ghana and management implications. FAJ; 8(4): 1-6

Ayode, AA (2011). Length -Weight Relationship and Diet of African Carp Labeo ogunensis (Boulenger, 1910) in Asejire Lake Southwestern Nigeria. JFAS; 27(1): 3-9

Bauchot, ML; Hureau, JC (1986). Sparidae. p. 883907. In P.J.P. Whitehead, M.-L. Bauchot, J.-C. Hureau, J. Nielsen and E. Tortonese (eds.) Fishes of the north-eastern Atlantic and the Mediterranean. volume 2. UNESCO, Paris.

Benina, R (2015). Biologie et exploitation de la Bougue Boops boops (Linné, 1758) dans la baie de Bou- Ismail191p.

Bensahla, TL (2014). Biologie et dynamique de la population du pageot argenté Pagellus acarne (Risso, 1827) pêché dans la baie d'Oran142 p. 
Beveridge, MCM; Thilsted, SH; Phillips, MJ; Metian, M; Troell, M; Hall, SJ (2013). Meeting the food and nutrition needs of the poor: The role of fish and the opportunities and challenges emerging from the rise of aquaculture. JFB; 83:1067-1084.

Carlander, KD (1969). Handbook of freshwater fishery biology, vol. 1. Ames, IA: The Iowa State University Press. p. 752.

Coutin, PC; Payne, AI (1989). The effects of long-term exploitation of demersal fish populations off the coast of Sierra Leone, West Africa. JFB; 35: 163167.

Cunha, NL; Catella, AC; Kinas, M.A (2007). Growth parameter estimates for a small fish of the Pantanal Brazil: Moenkhausiadichroura (Characiformes, Characidae). BJB; 67(2): 293297.

Dia, M; Wague, A; Ghorbel, M (2009). Etude de la reproduction chez Diplodus sargus cadenati (sparidae) de la cote de nouadhibou (mauritanie). Bulletin Institut National des Sciences et Technologies de la Mer de Salammbô 36, 2009.

Dobroslavić, T; Mozara, R; Glamuzina, B; Bartulović, V (2017). Reproductive patterns of bogue, Boops boops (Sparidae), in the southeastern Adriatic Sea. Original Scientific Paper ACTA ADRIAT 58(1), 117-125, 2017.

Druzhinin, AD; (1976). Sparid fishes of the world oceans. Moscow, Pishchevaya Promyshlennost, $195 \mathrm{p}$.

Famoofo, OO; Abdul, WO (2017). Biometry, condition factors and length-weight relationships of sixteen fish species in Iwopin fresh-water ecotype of Lekki Lagoon, Ogun State, Southwest Nigeria. CellPress-Heliyon; 6(1); e02957

Fontana, A (1969). Etude de la maturitésexuelle des sardinelles: Sardinellaeba (val.) etsardinellaaurita C. et $\mathrm{V}$. de la région de Pointe-Noire. O.R.S.T.O.M. Sérvice Océanographique; 7(2): 102-113.

Froese, R (2006). Cube law, condition factor and length- weight relationships history, metaanalysis and recommendations. JAI; 22: 241 253.

Gayanilo FC; Pauly, D; FAO-ICLARM stock assessment tools (FiSAT). Reference manual.
FAO Computerized Information Series (Fisheries). No. 8. Rome: FAO; 1997. p.262.

Konoyima, KJ; Mansaray, A; Ndomahina, ET; Amara, EB (2020). Length-Weight relationship and condition factor of Coelotilapiajoka (Thys van den Audenaerde, 1969) in the Rokel/Seli River, West Africa. ILNS; 77: 27-40.

Konoyima, KJ (2020). Sex Ratio, Stages of Gonad Development and Growth Pattern of Brachydeuterus Auritus and Pomadasys Jubelini in Sierra Leone, West Africa. IJBAIR, 2020, 9(2): 43-59.

doi:10.18052/www.scipress.com/ILNS.77.27

Kouame, AC; Sylla, S; Arra, S; Kouakou, KF; Yao, SS (2018). Parameters of Reproductive biology of Red Pandora Pagellus bellottii (Steindachner, 1882 ) in the Ivoirian coast (Cote d'Ivoire). JBES; 12 (4): 185-193.

Le Cren, ED (1951). The length-weight relationship and seasonal cycle in gonadal weight and condition in the perch (Percafluviatilis).JAE; 20: 271-279.

Neiland, AE; Cunningham, S; Arbuckle, M; Baio, A; Bostock, T; Coulibaly, D; Gitonga, NK; Long, R; Sei, S (2016). Assessing the potential contribution of fisheries to economic development: The case of post-ebola .SL.NR; 7:356-376

Pauly, D (1993).Fishbyte section editorial. Naga the ICLARM Quarterly, Rome, 16:pp.26-27

Pauly, D (1983).Linear Regressions in fisheries research. JFRBC; 30:409-434.

Pauly, D (1984). Fish population dynamics in tropical waters: A manual for use with programmable calculators. ICLARM Stud and Rev 8.ICLARM, Manila, p325.

Russell, B; Carpenter, KE (2014). Pagellus bellottii. The IUCN Red List of Threatened Species2014:e.T170162A1285147.http://dx.doi.o rg/10.2305/IUCN.UK.20143.RLTS.T170162A12 85147.

Showers, PAT (1993). Length-weight relationships of five species of the family Sparidae in the Gulf of Guinea. Naga ICLARM Q. 16(2\&3):32-33.

Súarez YR, Silva EA, Viana LF (2017). Reproductive biology of Astyanax lacustris (Characiformes: 
Characidae) in the southern Pantanal floodplain, upper Paraguay River basin, Brazil. JEBF: 775783.

Sylla, S; Zan-Bi, TT; Konan, KJ; Tia, CB; Kabre, JT; Kone, T (2016). Reproductive biology of big-eye grunt Brachydeuterusauritusin Ivory Coast fishery (West Africa). SJBS; 5(5): 158-166

Tesch, W (1971). Age and growth, p. 97-130. In W.E. Ricker(ed.). Methods for assessments of fish production in freshwaters. IBPOE.
Thomas J, Venu S, Kurup BM. Length-weight relationship of some deep-sea fish inhabiting the continental slope beyond $250 \mathrm{~m}$ depth along the west coast of India. NAGA ICLARM Quarterly. 2003; 26(2):17-21.

Torres, MA; Ramos, F; Sobrino, I (2012). Lengthweight relationships of 76 fish species from the Gulf of Cadiz (SW Spain). Fish. Res. 127128:171-175. 